\title{
Audit Premium, Brand Name Reputation, and Industrial Specialist: An Empirical Study of Private Universities and Colleges in Taiwan
}

\author{
Yung-Yu Lai \\ Overseas Chinese University, Taiwan \\ E-mail: caesar.larry@msa.hinet.net \\ Fu-Hsing Chang \\ Chihlee Institute of Technology, Taiwan \\ E-mail: cfs@mail.chihlee.edu.tw
}

Received: Nov. 2, 2013 Accepted: December 14, 2013 Published: December 14, 2013

doi:10.5296/ajfa.v5i2.4501ＵRL: http://dx.doi.org/10.5296/ajfa.v5i2.4501

\begin{abstract}
The main obstacle of audit fee research lies in fees collection. In the past, audit fees were usually collected by questionnaire survey method. This study however features itself by collecting first-hand audit fees data from the MOE directly via legislators and from the announcement after CPA association public bidding. This study examines not only types of tendering procedures but also audit revenue premiums about private universities and colleges in Taiwan in both brand name reputation and industry specialist perspectives. The results give support to our hypotheses. This study contributes some findings and significance. Firstly, the most important significance in the study, different from prior researches in which audit fees are paid by the client, we collect the unique data that audit fees are paid by the MOE. We can examine whether the effects of independent variables on audit fees are different from prior studies. Secondly, prior studies give evidence to support the agency theory, while we didn't find any research focused on real audit fees of NPOs applied the agency theory in Taiwan. Applying real audit fees, our results show that the agency theory is tenable for NPOs, especially the private universities and colleges. Thirdly, we propose some determinants of audit fees about the private universities and colleges. Finally, audit revenue premiums exist not only in profit organizations but also in NPOs.
\end{abstract}

Keywords: Audit fees, Audit Revenue Premium, Types of tendering procedures, Brand name reputation, Industry specialist 


\section{Introduction}

Numerous studies have investigated audit fees for profit organizations. However, nonprofit organizations (NPOs), one of the three biggest organization systems in society, have not received similar attention. ${ }^{1}$ Thorne et al. (2001), examined audit prices for government. They tested whether audit fees charged differently for different audit engagements using local governmental data collected from northern California. Nonprofit organizations (NPOs) cover a wide range of entities from hospitals, foundations, churches, and schools to museums. However, due to the difficulty of collecting audit fee information, only a few studies have focused on audit fees for NPOs. This research has not found a study focusing on audit premiums using actual NPO audit fees in Taiwan, especially for private universities and colleges. $^{2}$

Following a financial crisis at Hualien Da-Han Industrial and Business College in 1988 and an accounting scandal at Kaohsiung International Business College, the Ministry of Education (MOE) adopted strict controls over financial operations of private universities and colleges. Since then, the MOE has required that financial statements of universities and colleges be audited by auditing firms. The recent deregulation of founding private universities and colleges has increased public and private universities and colleges to a total number of 162 in 2006. The MOE started hiring auditors to audit private universities and colleges through open tendering procedures between 2001 and 2002. The MOE restricted bidder qualifications in 2003 to enhance auditors' abilities, and adopted limited tendering procedures to choose auditors and auditing fees. The tendering procedure uniquely appoints auditors in Taiwan.

What factors determine audit fees of private universities and colleges? Researches demonstrate that the main factors for profit organizations are client size (Simunic, 1980; Palmrose, 1986), client risk (Simunic, 1980), client complexity (Thornton and Zeghal, 1994), and auditor brand name reputation (Simunic, 1980; Craswell et al., 1995). Prior studies show that large audit firms systematically charge higher audit fees. According to the product differentiation economic theory (Klein and Leffler, 1981; Shapiro, 1983), large audit firms investing in a brand name for better audit quality positively relates to higher audit fees in competitive markets. The demand for audit quality differentiation can be explained as agent/contract costs (Simunic and Stein, 1987; Watts and Zimmerman, 1986). Most knowledge or experience of organizational management and audit are mainly obtained from profit organizations, and the mission and performance evaluation criteria of NPOs are different from those of profit organizations. Thus, studies on managing NPOs will face some obvious challenges. This study focuses not only on types of tendering procedures, but also on audit revenue premiums charged for better auditor brand name reputation and auditor industry specialization.

The purpose of this research is three-fold. Firstly, this investigation tests not only the effects of open tendering procedures, but also the effects of limited tendering procedures on audit fees. Secondly, this work examines the Big 4 audit fee-premiums behavior using samples collected from non-profit (private colleges and universities) rather than profit organizations. 
Thirdly, the current study divides the Big 4 audit fee-premiums into two components in terms of NPO features: brand name reputation and auditor industry specialization and different audit periods. The first component refers to the general auditor brand name premium, representing that audit revenue premium positively relates to auditor brand name. The second component is the auditor specialist premium, indicating that a positive relationship exists between audit revenue premiums and industry specialists of the Big 4.

The results give support to our hypotheses that: (1) CPA firms can get more revenue (audit fees) under limited tendering procedures are higher than those under open tendering procedures; (2) specialist Big 4 auditors can get more revenue (audit fees) than non-specialist Big 4 auditors; and (3) specialist Big 4 auditors can get more revenue (audit fees) than non-specialist Big 4 auditors. These findings are similar to the evidence from profit organizations and extend the literature.

Some findings and significance in the study include the following. Firstly, the current study significantly differs from prior researches in which the client pays audit fees. This work collects unique data and shows that the MOE is the responsible party for paying audit fees. This study also examines whether the effects of independent variables on audit fees are different from prior studies. Secondly, prior studies give evidence to support the agency theory, while this research does not find any research that focuses on real audit fees of NPOs applying the agency theory in Taiwan. Results from applying real audit fees show that the agency theory is tenable for NPOs, especially for private universities and colleges. Thirdly, this work proposes some determinants of audit fees concerning private universities and colleges. Finally, revenue premiums exist not only in profit organizations, but also in NPOs.

The remainder of this paper is organized into four sections. Section 2 reviews related literature and develops the hypotheses. Section 3 describes the sample selection and empirical design. Section 4 not only shows the empirical results but also contains sensitivity analyses to determine robustness of the results to alternative specifications. Section 5 provides a summary and conclusion.

\section{Literature Review and Research Hypotheses}

\subsection{Types of Tendering Procedures}

The MOE, in order to promote auditor independence, encouraged private school audits by auditors assigned by the MOE. As shown in Table 1, during the 1997-2000 academic years, the right to appoint auditors and the responsibility to pay for audit services was left to schools or remained with the MOE. The MOE changed the auditor selection process to enhance bidder qualifications, following the biggest educational scandal in 2000. As a result, the MOE selected auditors through tendering procedures, and was responsible for audit fees from 2001 to 2003. Since such practices represented different cost expenses, this study sampled data adopted from 2001-2003 to study the effects of different tendering procedures on audit fees. 
Table 1. Audit selector and responsible party for paying audit fees

\begin{tabular}{|c|c|c|}
\hline $\begin{array}{c}\text { Academic } \\
\text { year }^{3}\end{array}$ & Auditor selector & $\begin{array}{c}\text { Responsible party for paying } \\
\text { audit fees }\end{array}$ \\
\hline 1992 & Private universities and colleges & $\begin{array}{l}\text { Private universities and } \\
\text { colleges }\end{array}$ \\
\hline 1995 & Private universities and colleges & $\begin{array}{r}\text { Half of the audit fees was } \\
\text { subsidized by the MOE }\end{array}$ \\
\hline 1997 & $\begin{array}{l}\text { 1.Private universities and colleges, or } \\
\text { 2.assigned by the MOE }\end{array}$ & $\begin{array}{l}\text { 1.Private universities and } \\
\text { colleges, or } \\
\text { 2.the MOE when CPA was } \\
\text { assigned by the MOE }\end{array}$ \\
\hline 2001 & $\begin{array}{l}\text { The MOE entrusted the special case to audit } \\
\text { (Open tendering procedure) }\end{array}$ & The MOE \\
\hline 2003 & $\begin{array}{l}\text { The MOE entrusted the special case to audit } \\
\text { (Limited tendering procedure) }\end{array}$ & The MOE \\
\hline 2004 & Private universities and colleges & $\begin{array}{l}\text { Private universities and } \\
\text { colleges }\end{array}$ \\
\hline
\end{tabular}

Regulators in many countries have recently taken initiatives to enhance competition in the audit market. Changes to government regulations may provide the external impetus necessary to alter the underlying competitive environment. These changes can affect audit fees. Maher et al. (1992) report a decline in audit fees resulting from deregulation from 1977 to 1981 in a study of seventy-eight audits. Sanders et al. (1995) find a similar decline in audit fees from 1985 to 1989 in a study of 159 municipal audits. Their results support the argument that deregulation may enhance competition in the audit market and result in a decline in audit fees. That is, audit fees under regulation will be higher. Hackenbrack et al. (2000) examine the price and quality effects of an unusual state-mandated market restriction that required nonprice competition and prohibited price competition among auditors. They document that municipalities covered by the statute paid higher audit fees. The MOE entrusted auditors to audit the special case after examining bidder qualifications under a limited tendering procedure. This study expects that audit fees under limited tendering procedure will be higher and develops the following hypothesis:

H1: Ceteris paribus, audit fees under limited tendering procedures will be higher than those under open tendering procedures.

\subsection{Auditor Brand Name Reputation}

According to the product differentiation economic theory (Klein and Leffler, 1981; Shapior, 1983), large audit firms investing in brand name for better audit quality positively relates to higher audit fees in competitive markets. The demand for audit quality differentiation can be explained as agent/contract cost (Simunic and Stein, 1987; Watts and Zimmerman, 1986). Higher audit fees might result when firms recognize an auditor to be of superior quality to other firms. If firms perceive auditors as providing different quality services, some clients 
may demand, and be willing to pay more for, higher quality (Hay et al., 2006). Researchers have attempted to use a large number of different proxy variables to represent audit quality but the four that are most common are dummy variables for firms classified as being in the Big 8/6/5/4. For example, in the US audit market, Francis and Simon (1987) find an auditor brand name premium. Using UK data, Chan et al. (1993), Pong and Whittington (1994), and McMeeking et al. (2006) provide evidence supporting brand name premium. Francis (1984), DeFond et al. (2000) find existing brand name premiums in Australia, New Zealand, and Hong Kong, respectively. Craswell et al. (1995) examine audit revenue premiums received by the Big 8 using a sample of 1,484 Australian listed companies. On average, the Big 8 brand name premium over the non-Big 8 averages around 30\%. Klein and Leffer (1981), Palmrose (1986), and Simunic and Stein (1987) provide evidence consistent with existing brand name premiums due to better quality provided. In Taiwan, Wong (1999) find a brand name premium in his studies. In the meta-analysis papers which they consider, published over twenty-five years (1977-2002) and including more than twenty countries, Hay et al. (2006) find that the Big 8/6/5 associates with higher audit fees with $67 \%$ of all studies finding a significant positive result.

As for NPOs, Ward et al. (1994) document a Big-6 audit fee premium in their sample of Michigan municipalities comprising cities. In this research, the ratio of subsidiaries from government to total ordinary revenues is $13 \%$ for private universities and colleges. Agency theory about private universities and colleges indicates that CPA firms monitor schools on behalf of the government. Meanwhile, the ratio of tuition fees to total ordinary revenues is approximately $65 \%$ for private universities and colleges. The government also monitors schools on behalf of the students and the students' parents. This research expects that agency theory can be applied in NPOs, private universities and colleges, and the following hypothesis is developed:

H2: Ceteris paribus, non-specialist Big 4 auditors will have higher audit fees than non-Big 4 auditors.

\subsection{Auditor Industry Specialist Premium}

Accounting technology is an accounting system or accounting policies businesses use for reporting economic activities. In a general sense, accounting policies mainly relate to recognizing and measuring assets, debt and income from economic activities. If accounting technology is for a specific industry, both agent and contract problems of a business and accounting solutions will contain specific industrial characteristics. For example, specific industries may require some complicated contracts such as advanced contracts, long-term lease contracts, risk portfolio management contracts and off-balance sheet arrangements. Certain industries, such as the natural resources industry or the financial service industry may require specific accounting principles or financial reporting. An electronic data processing system and internal control system for the financial service industry are complicated and specific. Industrial specialization has led to auditor's specializing. This trend, however, significantly leads auditors to win a group of "specialism-based” clients. Therefore, specialist audit firms provide greater assurance for industries with specific contracts or accounting 
technology than those of non-specialist audit firms.

Many audit firms also recognize that investing in in-depth industry specific knowledge can have a valuable effect, contributing to firm brand name. Apart from normal requested returns, the large audit firm seeks higher audit fees to compensate for additional costs spent on industry specialization, compared to non-specialist audit firms. Alternatively, audit firms can achieve specialization by expanding market share.

Early researches of auditor industry specialists focused on industries with greater than thirty client firms (e.g. Craswell et al., 1995). Later studies (e.g. Ferguson et al., 2003) estimated revenue premiums in all industries, irrespective of the number of client firms within an industry. Craswell et al. (1995) examined audit revenue premiums received by the Big 8 using of a sample of 1,484 Australian listed companies. On average, industry specialist Big 8 auditors earn a 34\% premium over the non-specialist Big 8. In the meta-analysis covering a twenty-five-year period, Hay et al. (2006) found evidence consistent with an industry specialist premium. Carson and Fargher (2007) found an industry specialist premium in the Australian market for audit services. Industry leadership expecting a fee premium arises from expected returns for investing in specialization and from higher quality audits (Craswell et al., 1995) and also from city level reputation effects (DeFond et al., 2000; Ferguson et al., 2003). Higher audit quality associates with higher audit fee levels. The current study develops the following hypothesis:

H3: Ceteris paribus, specialist Big 4 auditors will have higher audit fees than non-specialist Big 4 auditors.

\section{Sampling and Modeling}

\subsection{Sampling}

The data of this research is collected from CPA firms appointed by the MOE to audit private universities and colleges for academic years 1998-2002. This research obtains information about audit fees and CPA audit firms from the MOE directly via legislators. The current work also obtains audit fees information for the 2003 academic year from the announcement after CPA association public bidding. According to the regulation in 'The Must-Dos list for CPA auditing, the Financial Statements of Junior Colleges and above', Article 6 regulates that service fees are limited to the audit fees on financial statements. The manually collected data contains not only the audit report, but also financial statements of private universities and colleges from each school website.

Table 2 lists audit fees of the MOE appointed CPA firms, public bidding and limited bidding CPA firms for the 1998-2003 academic years. The current study expects data shown in the table to be more accurate than using questionnaires by previous literature. Table 2 shows nine, ten, and fourteen schools between the 1998 and 2000 academic year that were audited by appointed CPAs, accounting for $10 \%$ of the whole. Due to the limited sample size for the 1998-2000 academic years, this investigation was unable to compare audit fee difference between academic years 1998-2000 and 2001-2003. The table obviously shows that the means of audit fees are not significantly different from each other during the academic year 
2001 and 2002; however, the mean of audit fees during the 2003 academic year is significantly higher than those of the previous two academic years.

Table 2. Audit fees of private colleges and universities by the MOE appointed project CPAs (expressed in New Taiwan dollars )

\begin{tabular}{cccccc}
\hline Year & No. of Obs. & Min & Mean & Max & SD \\
\hline 1998 & 9 & 300,000 & 388,889 & 700,000 & 151,186 \\
1999 & 10 & 380,000 & 563,000 & 930,000 & 151,375 \\
2000 & 14 & 410,000 & 613,714 & 950,000 & 196,656 \\
2001 & 101 & 142,500 & 293,350 & 850,480 & 128,495 \\
2002 & 101 & 142,500 & 292,237 & 830,000 & 126,863 \\
2003 & $100^{*}$ & 175,000 & 448,936 & 775,000 & 167,036 \\
\hline
\end{tabular}

*There are 104 private universities and colleges in 2003 academic years, with 4 schools' audit fees unavailable.

\subsection{Modeling}

The regression model used to examine the effects of tendering procedures and brand name reputation over audit fees ( $\mathrm{H} 1$ and $\mathrm{H} 2$ ), is specified as follows:

$$
\begin{gathered}
\text { LNAU }_{i}=a+b_{1} \text { YEARO3 }_{i}+b_{2} \text { YEARO2 }_{i}+b_{3} \text { BIG }_{i}+b_{4} \text { LNASSET }_{i} \\
+b_{5} \text { DEBT }_{i}+b_{6} \text { INT/EARN }_{i}+b_{7} \text { BOARD }_{i}+b_{8} \text { DONATE }_{i}+b_{9} \text { EARN }_{i} \quad+b_{10} \text { SUBSIDY }_{i} \\
+b_{11} \text { UNIV }_{i}+b_{12}{\text { OPP } / T A_{i}+\varepsilon_{i}}
\end{gathered}
$$

Where,

LNAU: natural log of the audit fee.

YEAR03: dummy variable, equals to one if academic year is 2003, and zero otherwise.

YEAR02: dummy variable, equals to one if academic year is 2002, and zero otherwise.

BIG4 : dummy variable, proxy for audit quality, equals to one if audited by Big 4, and zero otherwise.

LNASSET: natural log of total assets of private universities and colleges, proxy for size.

DEBT: the ratio of debt to total assets, proxy for risks.

INT/EARN: interest expenses divided by current net income/loss, proxy for risks.

BOARD: the ratio of board expenditures to current revenues, proxy for risks. 
DONATE: the ratio of personal donations to current revenues, proxy for risks.

EARN: the ratio of current earnings to current revenues, proxy for risks.

SUBSIDY: the ratio of subsidy to current revenues, proxy for risks.

UNIV : equals to one if university, and zero otherwise; proxy for complexity.

OPP/TA: the ratio of operating funds to total assets, proxy for complexity.

\subsubsection{Dependent variable}

This study uses the natural log of the audit fee (LNAU) as the dependent variable to reduce heteroskedasticity of the residual terms (Pamrose, 1986; Gul, 1999).

\subsubsection{Independent variables}

YEAR03 is a dummy variable, which equals to one if academic year is 2003, and zero otherwise and tests H1. This study predicts that audit fees under limited tendering procedures will be higher than those under open tendering procedures. We predict coefficient $b_{1}$ in Eq (1) to be positive.

BIG4 is a dummy variable, proxy for audit quality, which equals to one if audited by Big 4, and zero otherwise and tests H2. This study predicts an existing Big 4 premium. That is, we predict coefficient $\mathrm{b}_{3}$ in $\mathrm{Eq}(1)$ to be positive.

\subsubsection{Control variables}

Simunic (1980) presented a production view of the audit process and hypothesized that certain drivers associated with varying audit fees because those drivers caused an auditor to perform more (or less) work during the course of the audit. The general audit fee model is common to most studies in the literature represents audit fees as a function of client size, risk, client complexity, and quality (e.g. Craswell and Francis, 1999). Lin (1997) aims to generate audit fee models for listed companies in Taiwan. The results show that client size, audit risk, client complexity, and audit firm reputation significantly relate to audit fee variability. This study tests audit quality or audit firm reputation by hypotheses 2 and 3.

A meta-analysis provides a means of understanding the body of knowledge developed over more than twenty years in audit fee research. The study of Hay et al. (2006) confirms that well-established control variables for size, risk, and complexity relate to audit fees. Therefore, the current work uses size, risk, and complexity as control variables.

This study uses YEAR02 to control year effects. The main control variables are stated as follows:

\section{Client size}

The larger the clients, the greater the number of individual elements comprising the accounting systems as well as the greater the required number of formal control activities and thus the greater amount of input hours, audit efforts and audit fees required. Previous 
literature adopts the total asset variable to measure client size and to significantly explain audit fee variability in cross-sectional studies (Simunic, 1980; Francis, 1984; Craswell et al., 1995). Chow (1982) applies agency theory to observe motivations behind companies appointing auditors. Results indicate that client size appears to be vital in explaining why managers request audit services. Accordingly companies pay greater audit costs when audit efforts need to expand for large clients. Results across virtually all published studies found size to be the most dominant determinant of audit fees, which is expected to have a positive relationship with fees (Simunic 1980). The results of Hay et al. (2006), find size measures are overwhelmingly positive and significant.

Likewise, audit firms charge higher audit fees for private universities and colleges perceived to be larger. Therefore, this study uses a natural log of NPOs' total assets (LNASSET) as a proxy for client size to control the effects of client size on audit fees.

\section{Client risk}

Auditors consider auditee's risks in determining audit fees. Auditors may reduce follow-up audits to cut costs since auditors recognize NPO clients (private universities and colleges) with steady and strong financial structures as having low audit risk. In contrast, the higher the assessment level of auditee's risk, the higher the level of audit risk. A client with higher audit risk requires a greater amount of evidence to reduce audit risk, resulting in a correspondingly high audit fee. In a word, audit fees reflect the risk level of NPOs. Financial structures of private universities and colleges differ from those of profit organizations; the current study lacks insight into the relationship between debt ratio to total assets and audit fees. However, auditors consider other measures as a proxy for auditee's risk in deciding audit fees. This study proposes some proxy risk variables for private universities and colleges.

Leverage measures the risk of client failure, which potentially exposes the auditor to loss (Simunic, 1980). Consequently, researchers generally expect to find an association between leverage of a company and its audit fees. The first proxy this study uses for risk is the ratio of debt to total assets (DEBT). The second proxy for risk is the ratio of interest expenses to net income (INT/EARN).This research predicts a positive correlation between INT/EARN and the natural log of audit fees (LNAU). NPOs achieving better performance receive more donations from the private sector and greater financial support from the government, which in turn brings about a positive image for these NPOs. Thus, this work uses the ratio of subsidy to current revenues as a proxy for risk. In the same way, the ratio of personal donation to current revenues (DONATE) is also a proxy for risk. High ratio of current earnings to current revenue (EARN) represents a steady financial structure of an organization that leads to lower operational risk. These measures, except for INT/EARN, have an entirely negative impact on risks faced by NPOs, showing that such measures are negatively connected with audit fees.

Vafeas (1999) suggest that increasing number of board meetings increases board effectiveness. An effective board of directors of NPOs results in sound corporate governance of the school due to reduced organization's operational risk. All board expenditures should be debited to the Board's expense account which usually includes freight costs and operation costs. ${ }^{4}$ It states that all operation expenditures should relate to Board operation only, and does not 
allow any personal spending to be recorded on the accounts. This study therefore reasonably predicts that amount the board of directors spends closely depends on how effective the Board operates. A negative relationship between corporate governance of organization and audit fees is accordingly expected. The current work uses the ratio of board expenditures to current revenue (BOARD) as a proxy for corporate governance soundness with regard to private colleges and universities. The more effective NPO operations are, the better the corporate governance, hence the higher the related board expenditures. Therefore, this work expects a negative correlation between BOARD and the natural log of the audit fee (LNAU).

\section{Client complexity}

Researchers typically expect that the more complex a client, the harder it is to audit and the more time is consumed (Simunic, 1980; Hackenbrack and Knechel, 1994). The most typical indicator of complexity for profit organizations is the number of subsidiaries (Hay et al., 2006).

Compared with profit organizations or subsidiaries, private universities and colleges have subsidiary (e.g., hospital or kindergarten) operations that require more audit services and time as typical school operations and subsidiaries are totally different. Therefore, client complexity positively correlates to audit fees. A university organization is also larger and more complex compared to a college so that the universities have greater potential and more opportunities to acquire proposed projects and to develop continuous education than most colleges do. The current study also conjectures that auditors will charge a university higher audit fees than a college. As discussed above, this study uses two variables UNIV and OPP/TA to measure client complexity.

Since industry experts are all Big 4, the variable BIG4 very likely correlates with SPE, leading to the problem of variance inflation, and hence the multicollinearity problem. To avoid the above biases, when examining whether audit fees of the professional Big 4 are higher than those of the non-professional Big 4 in the industry with professional CPA firms, this research uses only the schools audited by the Big 4 to test hypothesis 3 . The model is as follows:

$$
\begin{aligned}
\text { LNAU }_{i}= & a+b_{1} \text { YEARO3 }_{i}+b_{2} \text { YEARO2 }_{i}+b_{3} \text { SPE }_{i}+b_{4} \text { LNASSET }_{i} \\
& +b_{5} \text { DEBT }_{i}+b_{6} \text { INT/EARN }_{i}+b_{7} \text { BOARD }_{i}+b_{8} \text { DONATE }_{i}+b_{9} \text { EARN }_{i}+ \\
& b_{10} \text { SUBSIDY }_{i}+b_{11} \text { UNIV }_{i}+b_{12}{\text { OPP } / T A_{i}+\varepsilon_{i}}^{\text {SUE }}
\end{aligned}
$$

where, SPE: professional CPA firms; equals to 1 when the ratio of audit fees over total audit fees of the schools is greater than $10 \%, 0$ otherwise. ${ }^{5}$ The other variables are defined the same as those in Eq (1).

Finally, this study uses the whole sample to test again: are audit fees of the professional Big 4 greater than those of the non-professional Big 4 CPA firms in the industry with professional CPA firms? The current work also tests whether audit fees charged by the non-professional 
Big 4 contain trademark premiums not found in the non-Big 4 CPA firms, i.e., when the reputation of attested CPA is higher, is the information value greater? Because professional CPA firms are all Big 4, therefore, the interaction term of BIG4 and SPE is the same as SPE; thus, we only employ SPE. Eq (3) is again used to test the hypotheses.

$$
\begin{aligned}
\text { LNAU }_{i}= & a+b_{1} \text { YEARO3 }_{i}+b_{2} \text { YEARO2 }_{i}+b_{3} \text { BIG }_{i}+b_{4} \text { SPE }_{i}+b_{5} \text { LNASSET }_{i} \\
& +b_{6} \text { DEBT }_{i}+b_{7} \text { INT/EARN }_{i}+b_{8} \text { BOARD }_{i}+b_{9} \text { DONATE }_{i}+b_{10} \text { EARN }_{i}+ \\
& b_{11} \text { SUBSIDY }_{i}+b_{12} \text { UNIV }_{i}+b_{13}{\text { OPP } / T A_{i}+\varepsilon_{i}}^{\text {SUI }}
\end{aligned}
$$

Where, SPE: professional CPA firms; equals to 1 when the ratio of audit fees over total audit fees of the schools is greater than $10 \%, 0$ otherwise. The other variables are defined the same as those in $\mathrm{Eq}(1)$.

To test robustness of the results, we use $15 \%$ as the threshold to define professional CPA firms in the sensitivity test. We also use (1) the ratio of the number of audited schools over total schools and (2) the ratio of total assets of schools audited over total schools' assets as the indicators of industry experts, and adopt $10 \%$ and $15 \%$ thresholds, separately, to do the sensitivity tests.

Table 3. Expected empirical results

\begin{tabular}{ccccc}
\hline $\begin{array}{c}\text { Independent } \\
\text { Variables }\end{array}$ & Eq(1) & Eq(2) & Eq(3) & $\begin{array}{c}\text { Expected } \\
\text { Signs }\end{array}$ \\
\hline YEAR03 & Hypothesis 1 & Hypothesis 1 & Hypothesis 1 & + \\
YEAR02 & Control variable & Control variable & Control variable & ? \\
BIG4 & Hypothesis 2 & -- & Hypothesis 2 & + \\
SPE & -- & Hypothesis 3 & Hypothesis 3 & + \\
LNASSET & Control variable & Control variable & Control variable & + \\
DEBT & Control variable & Control variable & Control variable & $?$ \\
INT/EARN & Control variable & Control variable & Control variable & + \\
BOARD & Control variable & Control variable & Control variable & - \\
DONATE & Control variable & Control variable & Control variable & - \\
EARN & Control variable & Control variable & Control variable & - \\
SUBSIDY & Control variable & Control variable & Control variable & - \\
UNIV & Control variable & Control variable & Control variable & + \\
OPP/TA & Control variable & Control variable & Control variable & + \\
\hline YEAR03:dummy variable, equals to one if academic year 2003, and zero otherwise. & & \\
YEAR02:dummy variable, equals to one if academic year 2002, and zero otherwise. & & \\
BIG4 dummy variable, proxy for audit quality, equals to one if audited by Big 4, and zero otherwise. & \\
SPE:professional CPA firms; equals to 1 when the ratio of audit fees over total audit fees of the schools is greater than 10\% or \\
15\%, 0 otherwise.
\end{tabular}


SUBSIDY:the ratio of subsidy to current revenues, proxy for risks.

UNIV :equals to one if university, and zero otherwise; proxy for complexity.

OPP/TA:the ratio of operating funds to total assets, proxy for complexity.

\section{Empirical Results and Analysis}

\subsection{Descriptive statistics}

Table 4 indicates the descriptive statistics of audit fees and financial data of sample schools for the 2001-2003 academic years. The average audit fee for the sample schools is NT\$344,496, and the minimum of that is NT\$142,500 whereas the maximum is NT\$850,480. Both the academic year 2002 and 2003 consists of 33\% of the sample. Approximately 39\% of the sample schools are audited by the Big 4 . The biggest school had total assets equivalent to NT\$14.74 billion and the smallest one had total assets about NT\$430 million; however, average total assets are NT $\$ 3.52$ billion. Generally speaking, the ratio of debt to total assets for private universities and colleges cannot be that high and so it ranges from $1 \%$ to $73 \%$ with a mean of $14 \%$. On average, the ratio of interest expenses to net income is $5 \%$ (maximum of $65 \%$ ). As for the ratio of personal donations to current revenues, the mean is $5 \%$ (maximum of $79 \%$ ). On average, the ratio of subsidy to current revenues is $13 \%$ (minimum of $3 \%$, maximum of $35 \%$ ). The average ratio of current earnings to current revenues is $28 \%$ (minimum of $-26 \%$, maximum of $70 \%$ ). Private universities made up $33 \%$ of the sample. As for the ratio of operating funds to total assets, the mean is $2 \%$ (maximum of $61 \%$ )

\subsection{Test of Multicollinearity}

Table 5 presents results of the Pearson correlation analysis. Among the independent variables, as Table 5 indicates, there are relatively high correlations between LNASSET and UNIV (0.692, significant at the 0.01 level), YEAR03 and BIG 4 (0.561, significant at the 0.01 level), BIG 4 and SPE(both $10 \%$ and 15\%), SPE(10\%) and SPE(15\%) , and the remaining coefficients are not higher than 0.5 . This work computes the variance inflation factor (VIF) to assess the susceptibility of the model to problems of multicollinearity. All the VIFs of variables fell below 3.0 which suggest that multicollinearity is unlikely to be problematic. 
Table 4. Descriptive statistics ( $\mathrm{n}=302$; expressed in New Taiwan dollars )

\begin{tabular}{ccccc}
\hline Variables & Mean & Minimum & Maximum & Std. Deviation \\
\hline AUDIT FEES & 344,496 & 142,500 & 850,480 & 159,459 \\
YEAR03 & 0.33 & 0.00 & 1.00 & 0.47 \\
YEAR02 & 0.33 & 0.00 & 1.00 & 0.47 \\
BIG4 & 0.39 & 0.00 & 1.00 & 0.49 \\
SPE (10\%) & 0.31 & 0 & 1 & 0.46 \\
SPE (15\%) & 0.20 & 0 & 1 & 0.40 \\
ASSET & $3,523,678,688$ & $429,949,870$ & $14,740,416,907$ & $2,689,134,236$ \\
DEBT & 0.14 & 0.01 & 0.73 & 0.13 \\
INT/EARN & 0.05 & -0.33 & 0.65 & 0.09 \\
BOARD & 0.0029 & 0.00 & 0.02 & 0.0035 \\
DONATE & 0.05 & 0.00 & 0.79 & 0.11 \\
EARN & 0.28 & -0.26 & 0.70 & 0.12 \\
SUBSIDY & 0.13 & 0.03 & 0.35 & 0.05 \\
UNIV & 0.33 & 0.00 & 1.00 & 0.47 \\
OPP/TA & 0.02 & 0.00 & 0.61 & 0.08 \\
\hline
\end{tabular}

AUDIT FEES:audit fees.

YEAR03:dummy variable, equals to one if academic year 2003, and zero otherwise.

YEAR02:dummy variable, equals to one if academic year 2002, and zero otherwise.

BIG4 :dummy variable, proxy for audit quality, equals to one if audited by Big 4, and zero otherwise.

SPE:professional CPA firms; equals to 1 when the ratio of audit fees over total audit fees of the schools is greater than $10 \%$ or $15 \%, 0$ otherwise.

ASSET :total assets of private universities and junior colleges, proxy for size.

DEBT :the ratio of debt to total assets, proxy for risks.

INT/EARN:interest expenses divided by current net income/loss, proxy for risks.

BOARD:the ratio of board expenditures to current revenues, proxy for risks.

DONATE:the ratio of personal donation to current revenues, proxy for risks.

EARN:the ratio of current earnings to current revenues, proxy for risks.

SUBSIDY:the ratio of subsidy to current revenues, proxy for risks.

UNIV :equals to one if university, and zero otherwise; proxy for complexity.

OPP/TA:the ratio of operating funds to total assets, proxy for complexity. 
Table 5. Pearson correlation matrices

\begin{tabular}{|c|c|c|c|c|c|c|c|c|c|c|c|c|c|c|}
\hline & YEAR03 & YEAR02 & BIG4 & $\begin{array}{c}\text { SPE } \\
(10 \%)\end{array}$ & $\begin{array}{c}\text { SPE } \\
(15 \%)\end{array}$ & LNASSET & DEBT & INT/EARN & BOARD & DONATE & SUBSIDY & EARN & UNIV & OPP/TA \\
\hline YEAR03 & 1 & $-0.499 * *$ & $0.561^{* *}$ & $0.500^{* *}$ & $0.452^{* *}$ & 0.072 & -0.079 & $-0.148 * *$ & 0.018 & -0.022 & $-0.174 * *$ & $-0.213^{* *}$ & 0.053 & 0.005 \\
\hline YEAR02 & & 1 & $-0.280 * *$ & $-0.219 * *$ & $-0.225^{* *}$ & 0.019 & 0.009 & -0.003 & -0.011 & -0.008 & 0.067 & 0.053 & 0.003 & 0.005 \\
\hline BIG4 & & & 1 & $0.839 * *$ & $0.615^{* *}$ & $0.211^{* *}$ & -0.017 & 0.010 & $-0.174 * *$ & $-0.133^{*}$ & $-0.218^{* *}$ & $-0.225 * *$ & $0.209 * *$ & 0.058 \\
\hline SPE(10\%) & & & & 1 & $0.733^{* *}$ & $0.201 * *$ & 0.000 & 0.016 & $-0.161^{* *}$ & $-0.143 *$ & $-0.209 * *$ & $-0.204 * *$ & $0.206^{* *}$ & 0.084 \\
\hline SPE(15\%) & & & & & 1 & $0.179 * *$ & -0.091 & -0.039 & $-0.189 * *$ & -0.103 & $-0.223 * *$ & $-0.197 * *$ & $0.129 *$ & -0.006 \\
\hline LNASSET & & & & & & 1 & $-0.343^{* *}$ & $-0.177 * *$ & $-0.469 * *$ & -0.006 & $-0.122^{*}$ & 0.063 & $0.692^{* *}$ & $0.371^{* *}$ \\
\hline DEBT & & & & & & & 1 & $0.655^{* *}$ & 0.063 & -0.075 & -0.106 & -0.021 & $-0.225^{* *}$ & $\begin{array}{c}-0.149 * \\
*\end{array}$ \\
\hline INT/EARN & & & & & & & & 1 & -0.006 & -0.041 & -0.107 & -0.071 & $-0.132 *$ & -0.099 \\
\hline BOARD & & & & & & & & & 1 & -0.068 & $0.122 *$ & $-0.194 * *$ & $-0.303 * *$ & -0.075 \\
\hline DONATE & & & & & & & & & & 1 & 0.017 & $0.489 * *$ & -0.038 & 0.075 \\
\hline SUBSIDY & & & & & & & & & & & 1 & $-0.114^{*}$ & 0.013 & -0.055 \\
\hline EARN & & & & & & & & & & & & 1 & -0.016 & $0.239 * *$ \\
\hline UNIV & & & & & & & & & & & & & 1 & $0.219 *$ \\
\hline ОРР/ТА & & & & & & & & & & & & & & 1 \\
\hline
\end{tabular}

YEAR03:dummy variable, equals to one if academic year 2003, and zero otherwise.

YEAR02:dummy variable, equals to one if academic year 2002, and zero otherwise.

BIG4 :dummy variable, proxy for audit quality, equals to one if audited by Big 4, and zero otherwise.

SPE:professional CPA firms; equals to 1 when the ratio of audit fees over total audit fees of the schools is greater than $10 \%$ or $15 \%$, 0 otherwise.

LNASSET :natural log of total assets of private universities and junior colleges, proxy for size.

DEBT :the ratio of debt to total assets, proxy for risks.

INT/EARN:interest expenses divided by current net income/loss, proxy for risks.

BOARD:the ratio of board expenditures to current revenues, proxy for risks.

DONATE:the ratio of personal donation to current revenues, proxy for risks.

EARN:the ratio of current earnings to current revenues, proxy for risks.

SUBSIDY:the ratio of subsidy to current revenues, proxy for risks.

UNIV :equals to one if university, and zero otherwise; proxy for complexity.

OPP/TA:the ratio of operating funds to total assets, proxy for complexity.

**Correlation is significant at the 0.01 level (2-tailed).

* Correlation is significant at the 0.05 level (2-tailed). 


\subsection{Results of regression models}

As Table 6 shows, of the 302 samples conducted for the 2001-2003 academic years, more than $10 \%$ of the entire sample group, defined as audit fees provided by one single audit firm, are industry specialists; and after filtration, ninety-four samples in total are cases handled by the BIG4 audit firms. When the threshold is increased to $15 \%$, fifty-nine sample cases are industry specialists.

Table 6. CPAs and types of private universities and colleges

\begin{tabular}{|c|c|c|c|c|c|c|}
\hline \multirow{2}{*}{ CPAs } & \multicolumn{3}{|c|}{$\begin{array}{c}\text { Specialist } \\
\text { (10\% threshold) }\end{array}$} & \multicolumn{3}{c|}{$\begin{array}{c}\text { Specialist } \\
\text { (15\% threshold) }\end{array}$} \\
\cline { 2 - 7 } & $\begin{array}{c}\text { Universities } \\
\text { and colleges }\end{array}$ & $\begin{array}{c}\text { Institutes of } \\
\text { technology }\end{array}$ & Total & $\begin{array}{c}\text { Universities } \\
\text { and colleges }\end{array}$ & $\begin{array}{c}\text { Institutes of } \\
\text { technology }\end{array}$ & Total \\
\hline Specialist & 33 & 61 & 94 & 19 & 40 & 59 \\
\hline $\begin{array}{c}\text { Non-specialist } \\
\text { Big 4 }\end{array}$ & 11 & 13 & 24 & 25 & 34 & 59 \\
\hline Non- Big 4 & 61 & 123 & 184 & 61 & 123 & 184 \\
\hline Total & 105 & 197 & 302 & 105 & 197 & 302 \\
\hline
\end{tabular}

Because of the close relationships between these two variables, the four major audit firms (BIG4) and the industry specialist (SPE), when the industry specialist accounts for $10 \%$ of the sampling population, the Pearson coefficient is 0.839 with $1 \%$ significance level and at $15 \%$, the Pearson coefficient is 0.731 at the $1 \%$ significance level. Therefore, when the regression model consists of both the BIG4 and SPE variables simultaneously, problems of collinearality may surface. Hence, when conducting the demonstration, Eq (1) is used to independently test the non-industry specialist samples, and to examine whether trademark premiums exist as stated in hypothesis 2. This is followed by an independent test using Eq (2) to examine the BIG4 samples to see whether an industry specialist premium exists in hypothesis 3 . Finally, Eq (3) is used to test the entire sample group for existing auditor brand name and industry specialist premiums.

When this research sets the specialist threshold at $10 \%$, there are two industry specialist firms: PricewaterhouseCoopers, which conducted audit services for fifty-nine schools (accounting for 29.38\% of the total sample during the three-year period) and Deloitte \& Touch, which completed audit services for thirty-five schools (not including cases before merging) during the three-year sampling period which accounts for $13.64 \%$ of the total sampling number. The percentages of audit fees accounted by the rest of the auditing firms are all below $10 \%$. When using (1) to exam the total occupancy rate of the school and (2) to exam the percentage of total school capital that accounts for the overall total school capital of the representative auditor industry specialists, the outcomes for categorized results and categorized audit fees are the same.

When proceeding with the demonstration, the sample is then separated into two groups of 
industry specialists and non-industry specialists; when the definition for industry specialists is set at $10 \%$, the samples collected of industry specialists and non-industry specialists are 94 and 208, respectively. When the threshold is defined at 15\%, the samples are 59 and 243. First, non-industry specialist samples were used to examine hypothesis 2. In an industry consisting of professional audit firms (specialists), the audit fees of the BIG4 non-specialist audit firms are higher than the non-BIG4 auditing firms, which demonstrate that the model is the same as Eq (1).

In the research conducted by Francis (1984), Craswell et al. (1995) and Palmrose (1986), the BIG6 audit firms charged higher fees due to higher quality auditing services they provided. Therefore when we use the scale of an auditing firm to represent its auditing quality, this work considers the scale as a variable element that affects audit fees. Table 7 shows the effects of trademarks on audit fees in an industry with specialized audit firms. By eliminating the four major specialized audit firms, this study compares the four major non-specialized firms to the four non-major firms to avoid confusions created by industry specialization. Because this particular test is limited to non-specialized firm samples, any differences in audit fees can be referred to trademark effects. Table 7 shows, when the specialization definition is set at $10 \%$, the four major non-specialized firms achieve the required significance level; and when the threshold is $15 \%$, the four major non-specialized firms have a coefficient of 0.1083 at the $1 \%$ significance level. This result is the same as anticipated by hypothesis 2. In an industry with specialized auditing firms, audit fees of the BIG4 non-specialized audit firms are higher than those of non-BIG4 audit firms. The differences between the BIG4 and non-BIG4 have already eliminated the effects caused by specialization. This result can independently refer to trademark effects of the BIG4. Other than DEBT and INT/EARN, which do not achieve significance, the other control variables are the same as anticipated and at the significance level.

This section examines whether audit fees of the BIG4 specialized audit firms are higher than the BIG4 non-specializing audit firms in an industry with specialized audit firms. This study uses 118 samples extracted from the school data examined by the four major audit firms to test hypothesis 3 . When using a $10 \%$ audit fee threshold to decide the industry specialists, ninety-four samples of the 118 total samples belong to industry specialists; when using 15\% audit fee threshold, fifty-nine samples of the 118 total samples belong to industry specialists. Table 8 shows the results. The coefficient of YEAR03 is significantly positive, supporting hypothesis 1 that audit fees under limited tendering procedures will be higher than those under open tendering procedures. When $10 \%$ is used as a threshold for deciding industry specialists, the specialist variable (SPE) does not reach the significance level. But when the threshold is set to a stricter $15 \%$, the coefficient on the SPE is 0.1689 at the $5 \%$ significance level. This proves that in an industry with specialists, limiting the samples to BIG4 clients controls the confusion created by trademark (BIG4 against non-BIG4) effects. There are differences between audit fees because the BIG4 are industry specialists. The result is consistent with hypothesis 3 that audit fees of the four major specialized audit firms are higher than the four major non-specialized audit firms. Results in Table 7 and Table 8 demonstrate that the Big 4 possesses trademark reputation and that the SPE variable of audit 
fee premium represents the positive return of the BIG 4 auditors and their investment in industry specialization.

Finally, in order to consolidate the results, Eq (3) is used with the entire 302 samples for demonstration. When the percentage of audit fee over the industry is at the $10 \%$ and $15 \%$ thresholds to decide industry specialist, ninety-four and fifty-nine cases belong to the specialist, respectively. Results in Table 9 show that all variables with VIFs values less than 4 have no serious variable inflation problems. The coefficient of YEAR03 is significantly positive, supporting hypothesis 1 that audit fees under limited tendering procedures will be higher than those under open tendering procedures. When the audit fee is over the $10 \%$ threshold of the entire industry audit fees, the BIG4 has a variable of 0.1437 at the $1 \%$ significance level. After controlling for the four major audit firms' influences, the industry specialist (SPE) variable coefficient is 0.0985 , the P-value is 0.0757 , and these gave hypotheses 2 and 3 very weak supporting evidence. When a stricter threshold is applied at $15 \%$, the coefficients of BIG4 and SPE are 0.1526 and 0.1674 , respectively, at the $1 \%$ significance level. Results show support for hypotheses 2 and 3 when Table 7 and Table 8 are analyzed separately. After controlling for possible effects of confusion created by the trademark premium (Big 4 against the non-Big 4 audit firms), the difference between audit fees is due to a public expense premium when the BIG4 are industry specialists. 
Table 7. Brand name effect of non-specialist audit firms

$$
\begin{aligned}
& \text { LNAU }_{\mathrm{i}}=a+b_{1} \text { YEAR03 }_{\mathrm{i}}+b_{2} \text { YEAR02 }_{\mathrm{i}}+b_{3} \text { BIG4 }_{\mathrm{i}}+b_{4} \text { LNASSET }_{\mathrm{i}} \\
& +b_{5} \mathrm{DEBT}_{\mathrm{i}}+b_{6} \mathrm{INT}_{\mathrm{EARN}}+b_{7} \mathrm{BOARD}_{\mathrm{i}}+b_{8} \mathrm{DONATE}_{\mathrm{i}}+b_{9} \mathrm{EARN}_{\mathrm{i}}+ \\
& b_{10} \mathrm{SUBSIDY}_{\mathrm{i}}+b_{11} \quad \mathrm{UNIV}_{\mathrm{i}}+b_{12} \mathrm{OPP}^{\mathrm{TTA}} \mathrm{i}_{\mathrm{i}}+\varepsilon_{i} \quad \mathrm{Eq}(1)
\end{aligned}
$$

\begin{tabular}{|c|c|c|c|c|c|c|}
\hline \multirow[b]{2}{*}{$\begin{array}{c}\text { Variable:LNA } \\
\mathrm{U}\end{array}$} & \multicolumn{3}{|c|}{$\begin{array}{c}\text { specialization is set to be over } \\
10 \% \text { of market share }\end{array}$} & \multicolumn{3}{|c|}{$\begin{array}{c}\text { specialization is set to be over } \\
15 \% \text { of market share }\end{array}$} \\
\hline & Coefficient & $p$-value & $V I F$ & Coefficient & $p$-value & $V I F$ \\
\hline Intercept & 7.2144 & 0.0000 & & 6.4308 & 0.0000 & \\
\hline YEAR03 & 0.2325 & 0.0000 & 1.4449 & 0.2714 & 0.0000 & 1.6723 \\
\hline YEAR02 & -0.0600 & 0.0204 & 1.2176 & -0.0528 & 0.0608 & 1.2604 \\
\hline BIG4 & 0.1238 & 0.0022 & 1.2499 & 0.1083 & 0.0015 & 1.4039 \\
\hline LNASSET & 0.2556 & 0.0000 & 2.6664 & 0.2903 & 0.0000 & 2.8452 \\
\hline DEBT & -0.0167 & 0.8883 & 1.9432 & -0.0803 & 0.5244 & 1.9700 \\
\hline INT/EARN & -0.2067 & 0.2412 & 1.8794 & 0.0937 & 0.5814 & 1.7988 \\
\hline BOARD & -9.9654 & 0.0036 & 1.3835 & -11.3069 & 0.0035 & 1.4340 \\
\hline DONATE & -0.3598 & 0.0013 & 1.5872 & -0.3616 & 0.0027 & 1.4298 \\
\hline EARN & -0.2955 & 0.0278 & 1.9701 & -0.2927 & 0.0240 & 1.7020 \\
\hline SUBSIDY & -1.3090 & 0.0000 & 1.1680 & -0.9987 & 0.0001 & 1.1074 \\
\hline UNIV & 0.1432 & 0.0001 & 1.8934 & 0.0845 & 0.0257 & 2.0260 \\
\hline OPP/TA & 0.9353 & 0.0000 & 1.2660 & 0.4986 & 0.0024 & 1.3034 \\
\hline R-squared & & 0.785 & & & 0.751 & \\
\hline Adjusted R-squar & red & 0.772 & & & 0.738 & \\
\hline F-statistic & & 59.304 & & & 57.817 & \\
\hline Prob(F-statistic) & & 0.000 & & & 0.000 & \\
\hline $\mathrm{N}$ & & 208 & & & 243 & \\
\hline
\end{tabular}

LNAU: the natural log of the audit fee.

YEAR03:dummy variable, equals to one if academic year 2003, and zero otherwise.

YEAR02:dummy variable, equals to one if academic year 2002, and zero otherwise.

BIG4 :dummy variable, proxy for audit quality, equals to one if audited by big 4 , and zero otherwise.

LNASSET :natural log of total assets of private universities and junior colleges, proxy for size.

DEBT :the ratio of debt to total assets, proxy for risks.

INT/EARN:interest expenses divided by current net income/loss, proxy for risks.

BOARD:the ratio of board expenditures to current revenues, proxy for risks.

DONATE:the ratio of personal donation to current revenues, proxy for risks.

EARN:the ratio of current earnings to current revenues, proxy for risks.

SUBSIDY:the ratio of subsidy to current revenues, proxy for risks.

UNIV :equals to one if university, and zero otherwise; proxy for complexity.

OPP/TA:the ratio of operating funds to total assets, proxy for complexity. 
Table 8. Brand name premium of specialist audit firms

\begin{tabular}{|c|c|c|c|c|c|c|}
\hline \multirow[b]{2}{*}{ Variable:LNAU } & \multicolumn{3}{|c|}{$\begin{array}{c}\text { specialization is set to be over } \\
10 \% \text { of market share }\end{array}$} & \multicolumn{3}{|c|}{$\begin{array}{l}\text { specialization is set to be over } 15 \% \\
\text { of market share }\end{array}$} \\
\hline & Coefficient & $p$-value & $V I F$ & Coefficient & $p$-value & VIF \\
\hline Intercept & 9.5709 & 0.0000 & & 9.1745 & 0.0000 & \\
\hline YEAR03 & 0.3545 & 0.0002 & 2.2323 & 0.3310 & 0.0003 & 2.2520 \\
\hline YEAR02 & 0.0404 & 0.7005 & 1.8772 & 0.0441 & 0.6642 & 1.8313 \\
\hline SPE & 0.1042 & 0.1671 & 1.1046 & 0.1689 & 0.0123 & 1.3934 \\
\hline LNASSET & 0.1497 & 0.0827 & 3.8665 & 0.1619 & 0.0563 & 3.8834 \\
\hline DEBT & -0.9201 & 0.0239 & 2.9264 & -0.7534 & 0.0599 & 2.9682 \\
\hline INT/EARN & 1.4869 & 0.0019 & 2.8510 & 1.4598 & 0.0018 & 2.8518 \\
\hline BOARD & -26.3068 & 0.1838 & 1.8105 & -8.3736 & 0.6887 & 2.1223 \\
\hline DONATE & -0.1461 & 0.7193 & 1.2599 & -0.1502 & 0.7044 & 1.2456 \\
\hline EARN & -0.5054 & 0.0940 & 1.3960 & -0.3712 & 0.2176 & 1.4573 \\
\hline SUBSIDY & -0.2163 & 0.7879 & 1.2402 & 0.0979 & 0.9027 & 1.2831 \\
\hline UNIV & 0.1007 & 0.2639 & 2.4243 & 0.1268 & 0.1536 & 2.4465 \\
\hline OPP/TA & 0.1942 & 0.5740 & 1.3498 & 0.2438 & 0.4678 & 1.3271 \\
\hline R-squared & & 0.447 & & & 0.470 & \\
\hline Adjusted R-squared & & 0.384 & & & 0.409 & \\
\hline F-statistic & & 7.075 & & & 7.748 & \\
\hline Prob(F-statistic) & & 0.000 & & & 0.000 & \\
\hline $\mathrm{N}$ & & 118 & & & 118 & \\
\hline
\end{tabular}

LNAU:the natural log of the audit fee.

YEAR03:dummy variable, equals to one if academic year 2003, and zero otherwise.

YEAR02:dummy variable, equals to one if academic year 2002, and zero otherwise.

SPE:professional CPA firms; equals to one when the ratio of audit fees over total audit fees is greater than $10 \%$ or $15 \%$, and zero otherwise.

LNASSET :natural log of total assets of private universities and junior colleges, proxy for size.

DEBT :the ratio of debt to total assets, proxy for risks.

INT/EARN:interest expenses divided by current net income/loss, proxy for risks.

BOARD:the ratio of board expenditures to current revenues, proxy for risks.

DONATE:the ratio of personal donation to current revenues, proxy for risks.

EARN:the ratio of current earnings to current revenues, proxy for risks.

SUBSIDY:the ratio of subsidy to current revenues, proxy for risks.

UNIV :equals to one if university, and zero otherwise; proxy for complexity.

OPP/TA:the ratio of operating funds to total assets, proxy for complexity. 
Table 9. Results of regression model for brand name premium and industry specialist with full sample

\begin{tabular}{|c|c|c|c|c|c|c|}
\hline \multirow[b]{2}{*}{ Variable:LNAU } & \multicolumn{3}{|c|}{$\begin{array}{c}\text { specialization is set to be over } \\
10 \% \text { of market share }\end{array}$} & \multicolumn{3}{|c|}{$\begin{array}{c}\text { specialization is set to be over } \\
15 \% \text { of market share }\end{array}$} \\
\hline & Coefficient & $p$-value & VIF & Coefficient & $p$-value & VIF \\
\hline Intercept & 7.5382 & 0.0000 & & 7.5596 & 0.0000 & \\
\hline YEAR03 & 0.2153 & 0.0000 & 2.0267 & 0.2020 & 0.0000 & 2.0447 \\
\hline YEAR02 & -0.0408 & 0.2315 & 1.3661 & -0.0356 & 0.2869 & 1.3610 \\
\hline BIG4 & 0.1437 & 0.0099 & 3.8622 & 0.1526 & 0.0002 & 2.1006 \\
\hline SPE & 0.0985 & 0.0757 & 3.4708 & 0.1674 & 0.0002 & 1.7438 \\
\hline LNASSET & 0.2406 & 0.0000 & 2.8276 & 0.2376 & 0.0000 & 2.8271 \\
\hline DEBT & -0.2074 & 0.1717 & 1.9987 & -0.1508 & 0.3131 & 2.0144 \\
\hline INT/EARN & 0.4337 & 0.0356 & 1.8807 & 0.4244 & 0.0362 & 1.8810 \\
\hline BOARD & -14.0938 & 0.0028 & 1.4364 & -12.2554 & 0.0086 & 1.4568 \\
\hline DONATE & -0.3457 & 0.0148 & 1.3743 & -0.3538 & 0.0110 & 1.3710 \\
\hline EARN & -0.3511 & 0.0160 & 1.6583 & -0.3119 & 0.0297 & 1.6690 \\
\hline SUBSIDY & -0.9973 & 0.0010 & 1.1669 & -0.8893 & 0.0030 & 1.1812 \\
\hline UNIV & 0.0684 & 0.0982 & 2.0070 & 0.0772 & 0.0577 & 2.0045 \\
\hline OPP/TA & 0.5242 & 0.0054 & 1.2805 & 0.5796 & 0.0017 & 1.2773 \\
\hline R-squared & & 0.698 & & & 0.708 & \\
\hline Adjusted R-squarec & & 0.684 & & & 0.695 & \\
\hline F-statistic & & 51.095 & & & 53.786 & \\
\hline Prob(F-statistic) & & 0.000 & & & 0.000 & \\
\hline $\mathrm{N}$ & & 302 & & & 302 & \\
\hline
\end{tabular}

LNAU:the natural log of the audit fee.

YEAR03:dummy variable, equals to one if academic year 2003, and zero otherwise.

YEAR02:dummy variable, equals to one if academic year 2002, and zero otherwise.

BIG4 :dummy variable, proxy for audit quality, equals to one if audited by Big 4, and zero otherwise.

SPE:professional CPA firms; equals to one when the ratio of audit fees over total audit fees is greater than $10 \%$ or $15 \%$, and zero otherwise.

LNASSET :natural log of total assets of private universities and junior colleges, proxy for size.

DEBT :the ratio of debt to total assets, proxy for risks.

INT/EARN:interest expenses divided by current net income/loss, proxy for risks.

BOARD:the ratio of board expenditures to current revenues, proxy for risks.

DONATE:the ratio of personal donation to current revenues, proxy for risks.

EARN:the ratio of current earnings to current revenues, proxy for risks.

SUBSIDY:the ratio of subsidy to current revenues, proxy for risks.

UNIV :equals to one if university, and zero otherwise; proxy for complexity.

OPP/TA:the ratio of operating funds to total assets, proxy for complexity. 


\section{Conclusions}

The main obstacle of audit fee research lies in fees collection. Previous audit fees were usually collected by questionnaire survey method. This study however collects audit fee data from audited financial statements of private colleges and universities for the 2001-2003 academic years. This study examines not only types of tendering procedures, but also audit revenue premiums for private universities and colleges in Taiwan according to both brand name reputation and industry specialist perspectives.

The evidence gives support for our first hypothesis (H1) that audit fees under limited tendering procedures will be higher than those under open tendering procedures. By excluding industry specialist Big 4, findings show a comparable result consistent with our second hypothesis (H2). The result shows that the auditor brand name reputation premium exists between non-specialist Big 4 and non-Big 4 while non-specialist Big 4 defined as an audit firm, has industry audit fees less than 15 percent. As auditing is a high specialization industry, an increase in audit fees charged by non-specialist Big 4 is expected to be naturally greater than those of non-Big 4. The coefficient estimated on SPE is also significant at the 0.05 level, revealing that specialist Big 4 has higher audit fees than those of non-Big 4. To assess robustness of the results, we reran the regression model with the full sample and the results remain consistent with those derived from subsamples. In sum, we conclude that differences in audit fee charges may attribute to revenue premiums for specialist Big 4 that supports our third hypothesis (H3), providing additional evidence to sustain auditor brand name reputation premium and industry specialist effects. The findings extend the literature.

This study contributes some findings and significance. Firstly, the most important significance in the study, different from prior researches in which audit fees are paid by the client, we collect the unique data that audit fees are paid by the MOE. We can examine whether the effects of dependent variables on audit fees are different from prior studies. Secondly, prior studies give evidence to support the agency theory, while we didn't find any research focused on real audit fees of NPOs applied the agency theory in Taiwan. Applying real audit fees, our results show that the agency theory is tenable for NPOs, especially the private universities and colleges. Thirdly, we propose some determinants of audit fees about the private universities and colleges. Finally, revenue premiums exist not only in profit organizations but also in NPOs.

Our study has several limitations. Nine, ten, and fourteen schools between the academic year 1998 and 2000 were audited by appointed CPAs, accounting for $10 \%$ of the whole. Due to limited research data, we were unable to compare audit fee differences between academic years 1998-2000 and 2001-2003. Furthermore, we were unable to collect audit fees from academic year 2004 and onward. Thus, this study cannot explore the effects of different auditor selectors, the MOE or private universities or colleges, on audit fees.

\section{Notes}

1. The three biggest organizations are profit organizations, non-profit organizations and government organizations. 
2. Universities and colleges include universities, colleges, and institutes of technology in this study, unless otherwise stated.

3. Academic years of schools are different from those of firms. For example, academic year 1992 started from August 1, 1992 and went to July 31, 1993.

4. According to Article 33 of the Private School Law, "The positions of chairman, director, and consultant shall all be non-paid, provided that stipends may be paid for meeting attendance and transportation.” Under the Administrative Rules Governing Special Audit at the Private Junior College and Higher Levels, the MOE specifies that the engaged auditors must pay attention to examining Board's expenditures.

5. According to Article 33 of the Private School Law, "The positions of chairman, director, and consultant shall all be non-paid, provided that stipends may be paid for meeting attendance and transportation." Under the Administrative Rules Governing Special Audit at the Private Junior College and Higher Levels, the MOE specifies that the engaged auditors must pay attention to examining Board's expenditures.

\section{References}

Anderson, T., \& Zeghal, D. (1994). The pricing of audit services: further evidence from the Canadian market. Accounting and Business Research, 24, 195-207. http://dx.doi.org/10.1080/00014788.1994.9729479

Carson, E., \& Fargher, N. L. (2007). Note on audit fee premiums to client size and industry specialization. Accounting and Finance, 423-446. http://dx.doi.org/10.1111/j.1467-629X.2007.00213.x

Chan, P., M. Ezzamel, \& Gwilliam, D. (1993). Determinants of audit fees for quoted UK companies. Journal of Business Finance and Accounting, 20, 765-786. http://dx.doi.org/10.1111/j.1468-5957.1993.tb00292.x

Chow, C. W. (1982). The demand for external auditing: size, debt and ownership influences. The Accounting Review, 57, 272-291.

Craswell, A. T., Francis, J. R., \& Taylor, S. L. (1995). Auditor brand name reputations and industry specializations. Journal of Accounting \& Economics, 20, 297-322. http://dx.doi.org/10.1016/0165-4101(95)00403-3

Craswell, A. T., \& Francis, J. R. (1999). Pricing initial audit engagements: A test of competing theories. The Accounting Review, 201-216. http://dx.doi.org/10.2308/accr.1999.74.2.201

DeFond, M.L., Francis, F.R., \& Wong, T.J. (2000). Auditor industry specialization and market segmentation: Evidence from Hong Kong. Auditing: A Journal of Practice and Theory, 19, 49-66. http://dx.doi.org/10.2308/aud.2000.19.1.49

Ferguson, A., Francis J. R., \& Stokes, D. (2003). The effects of firm-wide and office-level industry expertise on audit pricing. The Accounting Review, 429-448. 
http://dx.doi.org/10.2308/accr.2003.78.2.429

Francis, J. (1984). The effect of audit firm size on audit prices: A Study on the Australian Market. Journal of Accounting and Economics, 6, 133-151. http://dx.doi.org/10.1016/0165-4101(84)90010-7

Francis, J., \& Simon, D. (1987). A test of audit pricing in the small-client segment of the U.S. audit market. The Accounting Review, 62, 154-157.

Gul, F. (1999). Audit prices, product differentiation and economic equilibrium. Auditing: A Journal of Practice and Theory, 18, 90-100. http://dx.doi.org/10.2308/aud.1999.18.1.90

Hackenbrack, K., Jensen, K. L., \& Payne, J. L. (2000). The Effect of a bidding restriction on the audit services market. Journal of Accounting Research, 38(2), 355-374. http://dx.doi.org/10.2307/2672937

Hackenbrack, K., \& Knechel, W. R. (1997). Resource allocation decisions in audit engagements. Contemporary Accounting Research, 14(3), 481-500. http://dx.doi.org/10.1111/j.1911-3846.1997.tb00537.x

Hay, D. C., Kenchel, W. R., \& Wong, N. (2006). Audit fees: a Meta-analysis of the effect of supply and demand attributes. Contemporary Accounting Research, 141-191. http://dx.doi.org/10.1506/4XR4-KT5V-E8CN-91GX

Jerry T., Holmes, S. A., McGowan, A. S., Strand, C. A., \& Strawser, R. H. (2001). The relation between audit pricing and audit contract type: a public sector analysis. Journal of $\begin{array}{lllll}\text { Accounting and Public policy, 20, } & \text { 189-215. }\end{array}$ http://dx.doi.org/10.1016/S0278-4254(01)00026-6

Klein, B. \& Leffler, K. (1981). The role of market forces in assuring contractual performance. Journal of Political Economy, 89, 615-641. http://dx.doi.org/10.1086/260996

Lin, Y. C. (1997). A study of influential factors of audit fees. Master's thesis, Soochow University(in Mandarin).

Maher, M.W., Tiessen, P., Colson, R., and Broman, A.J. (1992). Competition and audit fees. The Accounting Review 67(January), 199-211.

McMeeking, K. P., Peasnell, K. V., \& Pope, P. F. (2006). The determinants of the UK Big Firm premium. Accounting and Business Research, 36(3), 207-231. http://dx.doi.org/10.1080/00014788.2006.9730022

Palmrose, Z. (1986). Audit fees and auditor size: further evidence. Journal of Accounting Research 24, 97-110. http://dx.doi.org/10.2307/2490806

Pong, C. M., \& Whittington, G. (1994). The determinants of audit fees: Some empirical models. Journal of Business Finance and Accounting, 21, 1071-1095. http://dx.doi.org/10.1111/j.1468-5957.1994.tb00365.x

Sanders, G., Arthur, A., \& Korte, L. (1995). Municipal audit fees: has increased competition 


\section{Macrothink}

made a difference. Auditing: A Journal of Practice and Theory, 14, 105-114.

Shapior, C. (1983). Premiums for high quality products as returns to reputations. Quarterly Journal of Economics, 98, 659-679. http://dx.doi.org/10.2307/1881782

Simon, D. T., \& Francis, J. R. (1988). The effects of auditor change on audit fees: tests of price cutting and price recovery. The Accounting Review, 63, 255-269.

Simunic, D. (1980). The pricing of audit services: theory and evidence. Journal of Accounting Research, 18, 161-190. http://dx.doi.org/10.2307/2490397

Simunic, D., \& Stein, M. (1987). Product differentiation in audit: auditor choice in the market for unseasoned new issues (Canadian Certified General Accountants' Research Foundation Vancouver).

Thorne, J., Holmes, S. A., McGowan, A. S., Strand, C. A., \& Strawser, R. H. (2001). The relation between audit pricing and audit contract type: a public sector analysis. Journal of $\begin{array}{lllll}\text { Accounting and Public } & \text { Policy, } & 20, & \text { 189-215. }\end{array}$ http://dx.doi.org/10.1016/S0278-4254(01)00026-6

Vafeas, N. (1999). Board meeting frequency and firm performance. Journal of Financial Economics, 53, 113-142. http://dx.doi.org/10.1016/S0304-405X(99)00018-5

Ward D., Elder, R., \& Kattelus, S. (1994). Further evidence on the determinants of municipal audit fees. The Accounting Review, 399-411.

Watts, R. L. \& Zimmerman, J. L. (1986). Positive Accounting Theory. Englewood Cliffs, NJ: Prentice-Hall.

Wong, W. K. (1999). The correlation among non-audit services, CPA size, and audit fees. Master's thesis, National Chung Cheng University (in Chinese). 